\title{
Evaluation of the Charm maximum residue limit $\beta$-lactam and tetracycline test for the detection of antibiotics in ewe and goat milk
}

\author{
M. C. Beltrán, ${ }^{* 1}$ T. Romero, ${ }^{*}$ R. L. Althaus, $\dagger$ and M. P. Molina* \\ *Instituto de Ciencia y Tecnología Animal, Universitat Politècnica de València, Camino de Vera, s/n. 46071, Valencia, Spain \\ †Cátedra de Biofísica, Facultad de Ciencias Veterinarias, Universidad Nacional del Litoral, R.P.L., Kreder 3080, Esperanza, Argentina
}

\section{ABSTRACT}

The Charm maximum residue limit $\beta$-lactam and tetracycline test (Charm MRL BLTET; Charm Sciences Inc., Lawrence, MA) is an immunoreceptor assay utilizing Rapid One-Step Assay lateral flow technology that detects $\beta$-lactam or tetracycline drugs in raw commingled cow milk at or below European Union maximum residue levels (EU-MRL). The Charm MRL BLTET test procedure was recently modified (dilution in buffer and longer incubation) by the manufacturers to be used with raw ewe and goat milk. To assess the Charm MRL BLTET test for the detection of $\beta$-lactams and tetracyclines in milk of small ruminants, an evaluation study was performed at Instituto de Ciencia y Tecnologia Animal of Universitat Politècnica de València (Spain). The test specificity and detection capability $(\mathrm{CC} \beta)$ were studied following Commission Decision 2002/657/ EC. Specificity results obtained in this study were optimal for individual milk free of antimicrobials from ewes (99.2\% for $\beta$-lactams and $100 \%$ for tetracyclines) and goats (97.9\% for $\beta$-lactams and $100 \%$ for tetracyclines) along the entire lactation period regardless of whether the results were visually or instrumentally interpreted. Moreover, no positive results were obtained when a relatively high concentration of different substances belonging to antimicrobial families other than $\beta$-lactams and tetracyclines were present in ewe and goat milk. For both types of milk, the CC $\beta$ calculated was lower or equal to EU-MRL for amoxicillin $(4 \mu \mathrm{g} / \mathrm{kg})$, ampicillin $(4 \mu \mathrm{g} / \mathrm{kg})$, benzylpenicillin $(\leq 2 \mu \mathrm{g} / \mathrm{kg})$, dicloxacillin $(30 \mu \mathrm{g} / \mathrm{kg})$, oxacillin $(30 \mu \mathrm{g} / \mathrm{kg})$, cefacetrile $(\leq 63 \mu \mathrm{g} /$ $\mathrm{kg})$, cefalonium $(\leq 10 \mu \mathrm{g} / \mathrm{kg})$, cefapirin $(\leq 30 \mu \mathrm{g} / \mathrm{kg})$, desacetylcefapirin $(\leq 30 \mu \mathrm{g} / \mathrm{kg})$, cefazolin $(\leq 25 \mu \mathrm{g} /$ $\mathrm{kg})$, cefoperazone $(\leq 25 \mu \mathrm{g} / \mathrm{kg})$, cefquinome $(20 \mu \mathrm{g} /$ $\mathrm{kg})$, ceftiofur $(\leq 50 \mu \mathrm{g} / \mathrm{kg})$, desfuroylceftiofur $(\leq 50 \mu \mathrm{g} /$ $\mathrm{kg})$, and cephalexin $(\leq 50 \mu \mathrm{g} / \mathrm{kg})$. However, this test could neither detect cloxacillin nor nafcillin at or below EU-MRL $(\mathrm{CC} \beta>30 \mu \mathrm{g} / \mathrm{kg})$. The CC $\beta$ for tetracyclines

Received August 8, 2012.

Accepted January 7, 2013.

${ }^{1}$ Corresponding author: mbeltran@dca.upv.es was also lower than EU-MRL for chlortetracycline (ewe milk: $\leq 50 \mu \mathrm{g} / \mathrm{kg}$; goat milk: $75 \mu \mathrm{g} / \mathrm{kg}$ ), oxytetracycline $(\leq 50 \mu \mathrm{g} / \mathrm{kg})$, and tetracycline $(\leq 50 \mu \mathrm{g} / \mathrm{kg})$. Regarding the 4-epimers of these tetracyclines only 4-epioxytetracycline was detected by the Charm MRL BLTET test below EU-MRL (ewe milk: $75 \mu \mathrm{g} / \mathrm{kg}$; goat milk: $\leq 50 \mu \mathrm{g} / \mathrm{kg}$ ). Acidiol had no effect on the performance of the test. The Charm MRL BLTET test could be used routinely with adapted test procedure for the fast screening of ewe and goat milk.

Key words: ewe and goat milk, antibiotic, receptorbinding assay, Rapid One-Step Assay (ROSA) Charm

\section{INTRODUCTION}

In dairy ewes and goats, just as in dairy cows, treatment of mastitis and other infectious diseases with pharmacological products is standard practice. In many cases, antibiotic milk contamination may be caused by treatments carried out without a veterinary prescription and with inadequate knowledge of the suitable dosage, administration route, or depletion time of the antibiotic substance (Molina et al., 2003a). This is partly because very few drugs on the market are specifically authorized for the use in lactating small ruminants, particularly goats, and occasionally veterinarians can prescribe drugs under cascade. Due to interspecies differences, available bovine data cannot be accurately extrapolated for the use in the dairy ewes and goats (Pengov and Kirbis, 2009). Drug residues in milk supplies not only have public health implications (Phillips et al., 2004; Sanders et al., 2011), but may also interfere in the manufacture of dairy products, such as cheese and yogurt (Packham et al., 2001; Berruga et al., 2011).

In some Mediterranean countries, such as Spain, France, Italy, and Greece, the production of ewe and goat milk plays a prominent role because of tradition and successful commercialization into products, such as different cheese and yogurt (Haenlein, 2001). For this reason, milk quality is mainly evaluated in terms of its technological or coagulation properties, which can be affected by the presence of antibiotic residue in milk.

To avoid risks related to drug residue, control of the presence of veterinary medicinal products in foodstuffs 
of animal origin at different stages of the production process is legally binding in many countries. The US Food and Drug Administration Center for Veterinary Medicine (FDA) established safe levels or tolerance of antibiotic residue in milk for consumer protection (FDA, 2005). In the European Union, the regulatory levels or Maximum Residue Limits (EU-MRL) are defined by Regulation (EC) 470/2009 (European Union, 2009) and established by Commission Regulation (EU) 37/2010 (European Union, 2010).

Currently, numerous screening tests are commercially available to detect all kinds of antibiotics in milk (IDF, 2010). Choosing a test depends on the control step (farms, dairies, or laboratories) and on the antibiotics used in milk production. In farms and dairies, receptorbinding assays are most commonly applied due to their simple and fast response. These methods, based on the use of specific receptors to detect antibiotics, were originally designed for the rapid detection of $\beta$-lactam antibiotics in cow milk (Charm and Zomer, 1995). In recent years these tests have been further developed, and specific receptor-binding assays are currently available for the detection of various antimicrobials, such as tetracyclines, gentamicin, enrofloxacin, or sulfonamides. Improvements made have also been directed at the reduction of the analysis period required and the inclusion of different receptors in one test type, having resulted in combined tests capable of detecting various groups of antibiotics simultaneously.

The Charm maximum residue limit $\beta$-lactam and tetracycline test (Charm MRL BLTET; Charm Sciences Inc., Lawrence, MA) is an immunoreceptor assay utilizing Rapid One-Step Assay (ROSA) lateral flow technology that detects $\beta$-lactam or tetracycline drugs in raw commingled cow milk at or below EU-MRL. This test is widely used for screening cow milk, and the test procedure was recently modified by the manufacturers to be used with raw milk from ewes and goats.

To assess the Charm MRL BLTET test for the detection of $\beta$-lactams and tetracyclines in milk of small ruminants, an evaluation study was performed at Instituto de Ciencia y Tecnologia Animal of Universitat Politècnica de València (Spain). The test specificity and detection capability $(\mathbf{C C} \boldsymbol{\beta})$ were studied following Commission Decision 2002/657/EC (European Union, 2002).

\section{MATERIALS AND METHODS}

\section{Milk Samples}

To obtain antibiotic-free milk samples along the entire lactation period, the experimental flocks of Manchega ewes of Universidad de Castilla-La Mancha (Albacete,
Spain) and Murciano-Granadina goats of Universitat Politècnica de València (Valencia, Spain) were used. Animals had good health status and did not receive veterinary treatment before or during the experimental period.

Test Specificity. Commission Decision 2002/657/ EC (European Union, 2002) describes specificity as the ability of a method to distinguish between the analyte being measured and other related substances, including the matrix constituents. According to this EC Regulation, specificity for the Charm MRL BLTET test was investigated using 2 approaches: (1) the false-positive rate was calculated when antibiotic-free milk samples were analyzed, (2) and the possible interferences related to the presence of substances belonging to antimicrobial families other than $\beta$-lactams and tetracyclines in milk samples (cross-reaction) were studied.

To calculate the false-positive rate of the Charm MRL BLTET test, individual milk samples $(200 \mathrm{~mL})$ from 25 ewes and 25 goats were collected every 2 wk throughout the entire lactation period. Ewe milk samples were obtained at morning milking from the first week after weaning until the end of lactation $(5 \mathrm{mo})$. Goat milk was collected from the second week postpartum for a period of $7 \mathrm{mo}$.

Milk samples were analyzed using MilkoScan 6000 (Foss, Hillerød, Denmark) to determine their chemical composition (fat, protein, and TS); SCC was obtained using Fossomatic 5000 (Foss); bacterial count was determined using Bactoscan FC (Foss); and $\mathrm{pH}$ value was measured by a conventional pH meter (Crison, Barcelona, Spain).

Antibiotic-free milk samples $(\mathrm{n}=250$ for ewes and $\mathrm{n}$ $=350$ for goats) were tested by using the Charm MRL BLTET test to assess the test specificity with each species. Samples giving positive results were retested (3 replicates); only samples showing positive results in at least 2 replicate analyses were classified as positive. Specificity was calculated as the percentage of negative samples with respect to the total of samples analyzed.

To check for interferences related to antimicrobial substances other than $\beta$-lactams and tetracyclines (cross-reaction), 20 individual raw milk samples free of antimicrobials, 10 for ewes and 10 for goats, were collected in the mid-lactation period. Milk samples were spiked individually with a relatively high concentration of different drugs and analyzed by Charm MRL BLTET test. In agreement with Reybroeck et al. (2010), the drug concentration in milk samples was $10 \times$ EU-MRL, and one substance was chosen from each of the most important groups of antimicrobials: neomycin (aminoglycosides), lincomycin (lincosamides), erythromycin (macrolides), colistin (polimyxins), enrofloxacin (quinolones), and sulfadiazine (sulfonamides). 
$\boldsymbol{C} \boldsymbol{C} \boldsymbol{\beta}$. The International Dairy Federation (IDF, 2002) establishes the requirements for milk samples selected for use as negative milk in the evaluation studies of screening tests for antibiotics detection. These requirements have been established only for cow milk. However, if a test is applied for milk of an animal species other than cows, the requirements with respect to the status of the animal should be adjusted accordingly.

Individual milk samples $(200 \mathrm{~mL})$ were collected in the mid-lactation period from 40 ewes $(>60$ and $<90 \mathrm{~d}$ postpartum) and 40 goats ( $>90$ and $<150 \mathrm{~d}$ postpartum). The samples were refrigerated at $4^{\circ} \mathrm{C}$ and were analyzed to determine their $\mathrm{pH}$, chemical composition, and hygienic quality within $24 \mathrm{~h}$ after milking using the analytical methods mentioned previously. For Manchega ewe milk, fat content was between 5 and $9 \%$, protein was between 4.7 and $8 \%$, and TS was between 15 and $22 \%$. Concerning hygienic quality, SCC was $<300 \times 10^{3}$ cell $/ \mathrm{mL}$ and bacterial count was $<10^{5} \mathrm{cfu} / \mathrm{mL}$. The $\mathrm{pH}$ value for ewe milk samples was between 6.6 and 6.8. For milk from Murciano-Granadina goats, fat content was between 3.3 and $7 \%$, protein was between 3.1 and $4.7 \%$, and TS was between 12 and $17 \%$. Somatic cell count was $<750 \times 10^{3}$ cell $/ \mathrm{mL}$ and bacterial count was $<10^{5} \mathrm{cfu} / \mathrm{mL}$. The $\mathrm{pH}$ value for goat milk was between 6.5 and 6.8 .

Selected antibiotic-free milk samples were analyzed by the Charm MRL BLTET test, and the samples giving negative results were spiked with different $\beta$-lactams and tetracyclines to calculate the $\mathrm{CC} \beta$ of this test. Detection capability was calculated according to the "Guidelines for the validation of screening methods for residues of veterinary medicines" proposed for Community Reference Laboratories Residues (CRL, 2010). This guideline document supplements Commission Decision 2002/657/EC, and defines CC $\beta$ as the concentration at which only $\leq 5 \%$ false compliant results remain. For authorized analytes, the concentration at which a screening test categorizes the sample as screen positive (potentially noncompliant), which triggers a confirmatory test, is called screening target concentration (STC) and it must be at or below EU-MRL. If the STC is set at half EU-MRL, the occurrence of one or no false-compliant results following the analysis of at least 20 screen positive control samples is sufficient to demonstrate that $\mathrm{CC} \beta$ is below EU-MRL and below or equal to $50 \%$ of EU-MRL. If STC is set between $50 \%$ and $90 \%$ of EU-MRL, at least 40 screen positive control samples with no more than 2 false-compliant results will be sufficient to demonstrate that $\mathrm{CC} \beta$ is below EU-MRL. If STC approaches EU-MRL $(<10 \%$ of EUMRL) a maximum of 60 replicates with no more than 3 false-compliant results is required to demonstrate that $\mathrm{CC} \beta$ is fit for this purpose. Antibiotic concentrations used for the calculation of the CC $\beta$ of the Charm MRL BLTET test were initially $0.5 \times$ EU-MRL $(20$ replicates); $0.75 \times$ EU-MRL (40 replicates); and $1 \times$ EUMRL (60 replicates), respectively, only when necessary.

Effect of Preservative Acidiol. To evaluate the effect of the preservative acidiol on the response of the Charm MRL BLTET test, antibiotic-free milk samples from 25 ewes and 25 goats were used. Individual milk samples were divided into 2 aliquots, 1 without preservative and 1 with acidiol, and analyzed by the Charm MRL BLTET test. Thereafter, each milk sample was spiked with benzylpenicillin and oxytetracycline at EU-MRL (4 and $100 \mu \mathrm{g} / \mathrm{kg}$, respectively) and analyzed again by the Charm MRL BLTET test.

Acidiol was prepared and used according to the Spanish regulation (Boletín Oficial del Estado, 2011), which stipulates the composition (0.75 g of chloramphenicol, $10 \mathrm{~mL}$ of ethanol, $18 \mathrm{~g}$ of sodium azide, $45 \mathrm{~g}$ of trisodium citrate $5.5 \cdot \mathrm{H}_{2} \mathrm{O}$, and $0.35 \mathrm{~g}$ of bromophenol blue in $1000 \mathrm{~mL}$ of distilled water) and the dosage of this preservative in ewe and goat milk $(133 \mu \mathrm{L}$ per $40 \mathrm{~mL}$ of raw milk).

\section{Antibiotics and Spiked Milk Samples}

The antibiotics used in this study were stored and handled according to the manufacturer's instructions before use. Drugs were dissolved $(1 \mathrm{mg} / \mathrm{mL})$ in water in a $25-\mathrm{mL}$ volumetric flask at the time when analyses were carried out. In some cases, the use of a small amount of a suitable solvent was necessary before adding water. Table 1 summarizes antibiotic commercial references and the solvent employed for the preparation of antibiotic stock solutions. Spiked milk samples were prepared following the recommendations of the International Dairy Federation (IDF, 2002) and milk analysis was performed within $4 \mathrm{~h}$ after spiking.

\section{Test Procedure}

The Charm MRL BLTET test was employed following the manufacturer's instructions. For ewes and goats, $300 \mu \mathrm{L}$ of milk sample was mixed with $300 \mu \mathrm{L}$ of the dilution buffer (sheep milk dilution buffer or goat milk dilution buffer, respectively; Charm Sciences Inc.) and refrigerated for $10 \mathrm{~min}$. Then, $300 \mu \mathrm{L}$ of the mixture was placed in the sample compartment of the strip placed in the ROSA Incubator (Charm Sciences Inc.). The incubation time was set at $56^{\circ} \mathrm{C}$ for $16 \mathrm{~min}$ (2 sets of $8 \mathrm{~min}$ ), and results were interpreted visually by 3 trained laboratory technicians and with the ROSA Reader (ROSA Pearl Reader, Charm Sciences Inc.).

The Charm MRL BLTET test uses receptors that bind $\beta$-lactam and tetracycline drugs. As milk flows 
Table 1. Antimicrobials used to evaluate the Charm maximum residue limit $\beta$-lactam and tetracycline test (Charm Sciences Inc., Lawrence, MA) in ewe and goat milk

\begin{tabular}{|c|c|c|c|}
\hline Antimicrobial & Distributor & $\begin{array}{l}\text { Commercial } \\
\text { reference }\end{array}$ & Solvent \\
\hline \multicolumn{4}{|l|}{ Aminoglycoside } \\
\hline Neomycin & Sigma-Aldrich ${ }^{1}$ & N1876 & $\mathrm{H}_{2} \mathrm{O}$ \\
\hline \multicolumn{4}{|l|}{$\beta$-Lactams } \\
\hline Amoxicillin & Sigma-Aldrich & A8523 & $\mathrm{H}_{2} \mathrm{O}$ \\
\hline Ampicillin & Sigma-Aldrich & A9518 & $\mathrm{H}_{2} \mathrm{O}$ \\
\hline Benzylpenicillin & Sigma-Aldrich & PENNA & $\mathrm{H}_{2} \mathrm{O}$ \\
\hline Cloxacillin & Sigma-Aldrich & C9393 & $\mathrm{H}_{2} \mathrm{O}$ \\
\hline Dicloxacillin & Sigma-Aldrich & D9016 & $\mathrm{MeOH} / \mathrm{H}_{2} \mathrm{O}$ \\
\hline Nafcilin & Sigma-Aldrich & N3269 & $\mathrm{MeOH} / \mathrm{H}_{2} \mathrm{O}$ \\
\hline Oxacillin & Sigma-Aldrich & 46589 & $\mathrm{MeOH} / \mathrm{H}_{2} \mathrm{O}$ \\
\hline Cefacetrile & Fatro $^{2}$ & $-^{3}$ & $\mathrm{H}_{2} \mathrm{O}$ \\
\hline Cefalonium & Sigma-Aldrich & 32904 & $0.1 \mathrm{~N} \mathrm{NaOH} / \mathrm{H}_{2} \mathrm{O}$ \\
\hline Cefapirin & Sigma-Aldrich & 43989 & $\mathrm{H}_{2} \mathrm{O}$ \\
\hline Desacetylcefapirin & ACS Dobfar ${ }^{4}$ & $-^{3}$ & $\mathrm{H}_{2} \mathrm{O}$ \\
\hline Cefazolin & Sigma-Aldrich & C5020 & $\mathrm{H}_{2} \mathrm{O}$ \\
\hline Cefoperazone & Sigma-Aldrich & 32426 & $0.1 \mathrm{~N} \mathrm{NaOH} / \mathrm{H}_{2} \mathrm{O}$ \\
\hline Cefquinome & Sigma-Aldrich & 32472 & $\mathrm{H}_{2} \mathrm{O}$ \\
\hline Ceftiofur & Sigma-Aldrich & 34001 & $0.1 \mathrm{~N} \mathrm{NaOH} / \mathrm{H}_{2} \mathrm{O}$ \\
\hline Desfuroylceftiofur & $\mathrm{TRC}^{5}$ & D289980 & $\mathrm{MeOH} / \mathrm{H}_{2} \mathrm{O}$ \\
\hline Cephalexin & Sigma-Aldrich & $\mathrm{C} 4895$ & $\mathrm{H}_{2} \mathrm{O}$ \\
\hline \multicolumn{4}{|l|}{ Lincosamides } \\
\hline Lincomycin & Sigma-Aldrich & 31727 & $\mathrm{H}_{2} \mathrm{O}$ \\
\hline \multicolumn{4}{|l|}{ Macrolides } \\
\hline \multirow{2}{*}{\multicolumn{4}{|c|}{ Polimyxins }} \\
\hline & & & \\
\hline Colistin & Sigma-Aldrich & C4461 & $\mathrm{H}_{2} \mathrm{O}$ \\
\hline \multicolumn{4}{|l|}{ Quinolones } \\
\hline Enrofloxacin & Sigma-Aldrich & 33699 & $\mathrm{AcOH} 5 \% / \mathrm{H}_{2} \mathrm{O}$ \\
\hline \multicolumn{4}{|l|}{ Sulfonamides } \\
\hline Sulfadiazine & Sigma-Aldrich & $\mathrm{S} 6387$ & $\mathrm{H}_{2} \mathrm{O}$ \\
\hline \multicolumn{4}{|l|}{ Tetracyclines } \\
\hline Chlortetracycline & Sigma-Aldrich & C4881 & $0.1 \mathrm{~N} \mathrm{NaOH} / \mathrm{H}_{2} \mathrm{O}$ \\
\hline 4-Epichlortetracycline & $\operatorname{Acros}^{6}$ & 268235000 & $\mathrm{MeOH} / \mathrm{H}_{2} \mathrm{O}$ \\
\hline Oxytetracycline & Sigma-Aldrich & O4636 & $0.1 \mathrm{~N} \mathrm{HCl} / \mathrm{H}_{2} \mathrm{O}$ \\
\hline 4-Epioxytetracycline & Acros & 25771 & $\mathrm{MeOH} / \mathrm{H}_{2} \mathrm{O}$ \\
\hline Tetracycline & Sigma-Aldrich & T3258 & $0.1 \mathrm{~N} \mathrm{HCl} / \mathrm{H}_{2} \mathrm{O}$ \\
\hline 4-Epitetracycline & Acros & 233125000 & $\mathrm{MeOH} / \mathrm{H}_{2} \mathrm{O}$ \\
\hline
\end{tabular}

${ }^{1}$ Sigma-Aldrich Química S.A. (Madrid, Spain).

${ }^{2}$ Fatro S.p.A. (Bologna, Italy).

${ }^{3}$ Product not available commercially (provided by the manufacturer).

${ }^{4}$ ACS Dobfar S.p.A. (Milan, Italy).

${ }^{5}$ Toronto Research Chemicals Inc. (Toronto, Canada).

${ }^{6}$ Acros Organics (Geel, Belgium).

through the test strip, unreacted receptors bind at the BL ( $\beta$-lactam) or TET (tetracycline) position and form a visible reddish test line. A weaker intensity $\mathrm{BL}$ or TET line forms when $\beta$-lactam or tetracycline drugs are present in the milk sample. Visual interpretation of the results was carried out by comparing the $\mathrm{BL}$ and TET lines with the control $(\mathbf{C})$ line. If both lines are darker than or equal to the $\mathrm{C}$ line, the milk sample is negative (antibiotic-free). If either the BL or TET line is lighter than the $\mathrm{C}$ line or the $\mathrm{BL}$ or TET line does not form, the sample is positive (likely antibiotic presence).

The performance of the reader system was checked daily by low and high calibration strips and by testing negative and positive control standards (benzylpenicil- lin: $4 \mu \mathrm{g} / \mathrm{kg}$; oxytetracycline: $100 \mu \mathrm{g} / \mathrm{kg}$; Charm MRL BLTET Positive tablet, Charm Sciences Inc.) before testing samples. Milk samples giving a reader value $\leq 0$ were considered negative, whereas milk samples giving a reader value $>0$ were considered positive.

\section{Statistical Analysis}

To assess the effect of the reading system used for the interpretation of the test results (visual or instrumental) on the test response, a chi-squared test was used. When an expected frequency was $<5$ the Fisher's exact test was applied. A significant difference was defined by $P<0.05$. Statistical analysis was performed using SAS (version 9.2, 2001; SAS Institute Inc., Cary, NC). 
Table 2. Quality parameters of ewe and goat milk samples obtained throughout the entire lactation period

\begin{tabular}{|c|c|c|c|c|c|c|c|c|}
\hline Parameter & \multicolumn{4}{|c|}{ Ewe milk $(\mathrm{n}=250)$} & \multicolumn{4}{|c|}{ Goat milk $(\mathrm{n}=350)$} \\
\hline $\mathrm{pH}$ & 6.67 & 0.08 & 6.52 & 6.92 & 6.78 & 0.09 & 6.55 & 7.13 \\
\hline Protein (\%) & 5.81 & 0.72 & 4.55 & 7.82 & 3.82 & 0.48 & 2.68 & 6.03 \\
\hline TS (\%) & 18.02 & 2.54 & 12.51 & 26.53 & 15.0 & 1.51 & 12.13 & 20.48 \\
\hline $\mathrm{BC}^{1}\left(\times 10^{3} \mathrm{cfu} / \mathrm{mL}\right)$ & 566 & 1,508 & 6 & 9,999 & 74 & 306 & 10 & 4,829 \\
\hline
\end{tabular}

${ }^{1} \mathrm{BC}=$ bacterial count.

\section{RESULTS AND DISCUSSION}

\section{Test Specificity}

Table 2 summarizes the chemical composition and hygienic quality of the individual milk samples used to assess the false-positive rate of the Charm MRL BLTET test. Mean milk sample quality parameters were similar to those reported by other authors for ewe (Requena et al., 2010) and goat milk (Salama et al., 2003).

According to the instrumental interpretation (Table 3), specificity of the Charm MRL BLTET test with adapted assay procedure for the detection of $\beta$-lactam antibiotics (BL line) was $99.2 \%$ for ewe milk (a falsepositive rate of $0.8 \%$ ) and $97.9 \%$ for goat milk (a false-positive rate of $2.1 \%$ ). Specificity was $100 \%$ for the detection of tetracyclines (TET line) in ewe and goat milk (no false-positive results). In all cases, the specificity calculated according to the visual interpretation of the results was slightly lower than that obtained by the ROSA Reader, but no statistically significant differences were found $(P>0.05)$.

Specificity results obtained in this study were optimal for both types of milk and indicate that the characteristics of the milk do not influence the test response. The few goat milk samples that were classified as positive (7 false-positive results) had standard characteristics of the Murciano-Granadina breed. The mean values for the quality parameters considered were as follows: $\mathrm{pH}$ :
6.73; fat: $6.47 \%$; protein: $4.12 \%$; TS: $16.04 \%$; SCC: 519 $\times 10^{3} \mathrm{cell} / \mathrm{mL}$; and BC: $62 \times 10^{3} \mathrm{cfu} / \mathrm{mL}$.

Only a limited number of evaluation studies of receptor-binding assays in ewe and goat milk are available. Reybroeck et al. (2010) obtained a specificity for the Betastar $(1+1)$ test (Neogen Corporation, Lansing, MI) of $96.8 \%$ for ewe milk and $96.5 \%$ for goat milk. The same result (96.7\%) was obtained by Zeng et al. (1998) for the SNAP Betalactam test (Idexx Laboratories, Westbrook, ME) using raw commingled goat milk.

Berruga et al. (2009), using the Charm MRL BLTET test in ewe milk, obtained a lower specificity for the detection of $\beta$-lactam antibiotics (90\%) and a similar specificity (99\%) for tetracyclines. Although these authors also used individual ewe milk for the evaluation of this test, it must be emphasized that they followed the same procedure recommended for cow milk (no buffer dilution used and incubation time at $56^{\circ} \mathrm{C}$ for $8 \mathrm{~min}$ ), which could explain the differences observed.

Specificity of the Charm MRL BLTET test obtained in this study with adapted test procedure for individual goat milk (97.4 and $97.9 \%$ for visual or instrumental interpretation, respectively) was similar to that found by Reybroeck et al. (2011) using the $\beta$-lactam screening test Charm MRL-3 test (Charm Sciences Inc.) with individual cow's milk samples $(97.6 \%)$. This low falsepositive rate (between 2.1 and $2.6 \%$ ) could be related

Table 3. Specificity (false-positive rate) of the Charm maximum residue limit $\beta$-lactam (BL) and tetracycline (TET) test (Charm Sciences Inc., Lawrence, MA) in antibiotic-free milk from ewes and goats with adapted test procedure

\begin{tabular}{|c|c|c|c|c|c|c|c|c|}
\hline \multirow[b]{3}{*}{ Milk sample } & \multirow{3}{*}{$\begin{array}{l}\text { Test } \\
\text { line }\end{array}$} & \multicolumn{7}{|c|}{ Result $^{1}$} \\
\hline & & \multicolumn{4}{|c|}{ Visual } & \multicolumn{3}{|c|}{ Instrumental } \\
\hline & & P (no.) & Q (no.) & N (no.) & $\mathrm{S}(\%)$ & P (no.) & N (no.) & $\mathrm{S}(\%)$ \\
\hline \multirow[t]{2}{*}{ Ewes $(\mathrm{n}=250)$} & BL & 2 & 1 & 247 & 98.8 & 2 & 248 & 99.2 \\
\hline & TET & 0 & 0 & 250 & 100 & 0 & 250 & 100 \\
\hline \multirow[t]{2}{*}{ Goats $(\mathrm{n}=350)$} & BL & 7 & 2 & 341 & 97.4 & 7 & 343 & 97.9 \\
\hline & TET & 0 & 1 & 349 & 99.7 & 0 & 350 & 100 \\
\hline
\end{tabular}

${ }^{1} \mathrm{P}=$ positive; $\mathrm{Q}=$ questionable; $\mathrm{N}=$ negative; $\mathrm{S}(\%)=$ specificity = negatives $/$ total $\times 100$. 
Table 4. Detection capability $(\mathrm{CC} \beta)$ of the Charm maximum residue limits $\beta$-lactam and tetracycline test (Charm Sciences Inc., Lawrence, MA) for antibiotics in ewe milk with adapted test procedure

\begin{tabular}{|c|c|c|c|c|c|}
\hline Antimicrobial & $\begin{array}{c}\text { EU-MRL }^{1} \\
(\mu \mathrm{g} / \mathrm{kg})\end{array}$ & $\begin{array}{c}\mathrm{STC}^{2} \\
(\mu \mathrm{g} / \mathrm{kg})\end{array}$ & $\begin{array}{l}\text { Positive/total } \\
\text { samples }\end{array}$ & $\begin{array}{l}\text { Positive } \\
\text { results }(\%)\end{array}$ & $\begin{array}{c}\mathrm{CC} \beta \\
(\mu \mathrm{g} / \mathrm{kg})\end{array}$ \\
\hline \multicolumn{6}{|l|}{$\beta$-Lactam } \\
\hline Amoxicillin & 4 & 4 & $57 / 60$ & 95 & 4 \\
\hline Ampicillin & 4 & 4 & $58 / 60$ & 97 & 4 \\
\hline Benzylpenicillin & 4 & 2 & $19 / 20$ & 95 & $\leq 2$ \\
\hline Cloxacillin & 30 & 30 & $11 / 60$ & 18 & $>30$ \\
\hline Dicloxacillin & 30 & 30 & $57 / 60$ & 95 & 30 \\
\hline Nafcilin & 30 & 30 & $22 / 60$ & 37 & $>30$ \\
\hline Oxacillin & 30 & 30 & $59 / 60$ & 98 & 30 \\
\hline Cefacetrile & 125 & 63 & $20 / 20$ & 100 & $\leq 63$ \\
\hline Cefalonium & 20 & 10 & $20 / 20$ & 100 & $\leq 10$ \\
\hline Cefapirin & $60^{4}$ & 30 & $20 / 20$ & 100 & $\overline{\leq} 30$ \\
\hline Desacetylcefapirin & -5 & 30 & $20 / 20$ & 100 & $\leq 30$ \\
\hline Cefazolin & 50 & 25 & $20 / 20$ & 100 & $\overline{\leq} 25$ \\
\hline Cefoperazone & 50 & 25 & $20 / 20$ & 100 & $\leq 25$ \\
\hline Cefquinome & 20 & 20 & $60 / 60$ & 100 & 20 \\
\hline Ceftiofur & $100^{6}$ & 50 & $20 / 20$ & 100 & $\leq 50$ \\
\hline Desfuroylceftiofur & -5 & 50 & $20 / 20$ & 100 & $\leq 50$ \\
\hline Cephalexin & 100 & 50 & $20 / 20$ & 100 & $\leq 50$ \\
\hline \multicolumn{6}{|l|}{ Tetracycline } \\
\hline Chlortetracycline & $100^{7}$ & 50 & $20 / 20$ & 100 & $\leq 50$ \\
\hline 4-Epichlortetracycline & -5 & 100 & $0 / 60$ & 0 & $>100$ \\
\hline Oxytetracycline & $100^{7}$ & 50 & $20 / 20$ & 100 & $\leq 50$ \\
\hline 4-Epioxytetracycline & -5 & 75 & $40 / 40$ & 100 & 75 \\
\hline Tetracycline & $100^{7}$ & 50 & $20 / 20$ & 100 & $\leq 50$ \\
\hline 4-Epitetracycline & $-^{5}$ & 100 & $0 / 60$ & 0 & $>\overline{1} 00$ \\
\hline \multicolumn{6}{|c|}{${ }^{1}$ EU-MRL $=$ European Union maximum residue limits. } \\
\hline \multicolumn{6}{|c|}{${ }^{2} \mathrm{STC}=$ screening target concentration. } \\
\hline \multicolumn{6}{|c|}{$\begin{array}{l}{ }^{3} \text { According to CRL }(2010), \mathrm{STC}=0.5 \times \text { EU-MRL: } 20 \text { samples; } \mathrm{STC}=0.75 \times \text { EU-MRL: } 40 \text { samples; STC } \\
1 \times \text { EU-MRL: } 60 \text { samples. }\end{array}$} \\
\hline \multicolumn{6}{|c|}{${ }^{4}$ Sum of cefapirin and desacetylcefapirin. } \\
\hline \multicolumn{6}{|c|}{${ }^{5}$ Marker residue; EU-MRL not established. } \\
\hline \multicolumn{6}{|c|}{${ }^{6}$ Sum of all residues retaining the $\beta$-lactam structure expressed as desfuroylceftiofur. } \\
\hline
\end{tabular}

to the use of individual milk samples, as these same authors calculated a specificity of $99.3 \%$ when analyzing farm milk samples from cows. On the contrary, for ewe and goat milk, a high incidence of false-positive results (10/12 and 6/8, respectively) was obtained, suggesting that the Charm MRL-3 test is not suitable for the detection of $\beta$-lactam antibiotics in non-cow milk samples. Also, Salter et al. (2011) indicate a specificity of $100 \%$ for raw commingled milk from cows for the Charm 3 SL3 $\beta$-Lactam test (Charm Sciences Inc.).

Regarding the cross-reaction study for the Charm MRL BLTET test, no positive results were obtained when a relatively high concentration $(10 \times$ EU-MRL $)$ of different substances belonging to antimicrobial families other than $\beta$-lactams and tetracyclines were present in ewe and goat milk. These results are similar to those found by Reybroeck et al. (2011) and Salter et al. (2011), neither of whom found interferences due to the presence of other non- $\beta$-lactam antimicrobials in milk from cows using the Charm MRL-3 test and Charm 3 SL3 $\beta$-Lactam test, respectively.

\section{$C C \beta$}

Detection capability results of the Charm MRL BLTET with adapted test procedure for different $\beta$-lactams and tetracyclines in ewe and goat milk were evaluated. The CC $\beta$ values calculated according to the visual interpretation of the results were the same as those obtained by the ROSA Reader and are summarized in Tables 4 and 5 .

For both types of milk, the CC $\beta$ calculated was lower than EU-MRL for benzylpenicillin $(\leq 2 \mu \mathrm{g} / \mathrm{kg})$, cefacetrile $(\leq 63 \mu \mathrm{g} / \mathrm{kg})$, cefalonium $(\leq 10 \mu \mathrm{g} / \mathrm{kg})$, cefapirin $(\leq 30 \mu \mathrm{g} / \mathrm{kg})$, desacetylcefapirin $(\leq 30 \mu \mathrm{g} / \mathrm{kg})$, cefazolin $(\leq 25 \mu \mathrm{g} / \mathrm{kg})$, cefoperazone $(\leq 25 \mu \mathrm{g} / \mathrm{kg})$, ceftiofur $(\leq 50$ $\mu \mathrm{g} / \mathrm{kg})$, desfuroylceftiofur $(\leq 50 \mu \mathrm{g} / \mathrm{kg})$, and cephalexin $(\leq 50 \mu \mathrm{g} / \mathrm{kg})$. The Charm MRL BLTET CC $\beta$ was equal to EU-MRL for amoxicillin $(4 \mu \mathrm{g} / \mathrm{kg}$ ), ampicillin (4 $\mu \mathrm{g} / \mathrm{kg})$, dicloxacillin $(30 \mu \mathrm{g} / \mathrm{kg})$, oxacillin $(30 \mu \mathrm{g} / \mathrm{kg})$, and cefquinome $(20 \mu \mathrm{g} / \mathrm{kg})$. However, this test could not detect cloxacillin or nafcillin at or below EU-MRL $(\mathrm{CC} \beta>30 \mu \mathrm{g} / \mathrm{kg})$. 
Table 5. Detection capability $(\mathrm{CC} \beta)$ of the Charm maximum residue limits $\beta$-lactam and tetracycline test (Charm Sciences Inc., Lawrence, MA) for antibiotics in goat milk with adapted test procedure

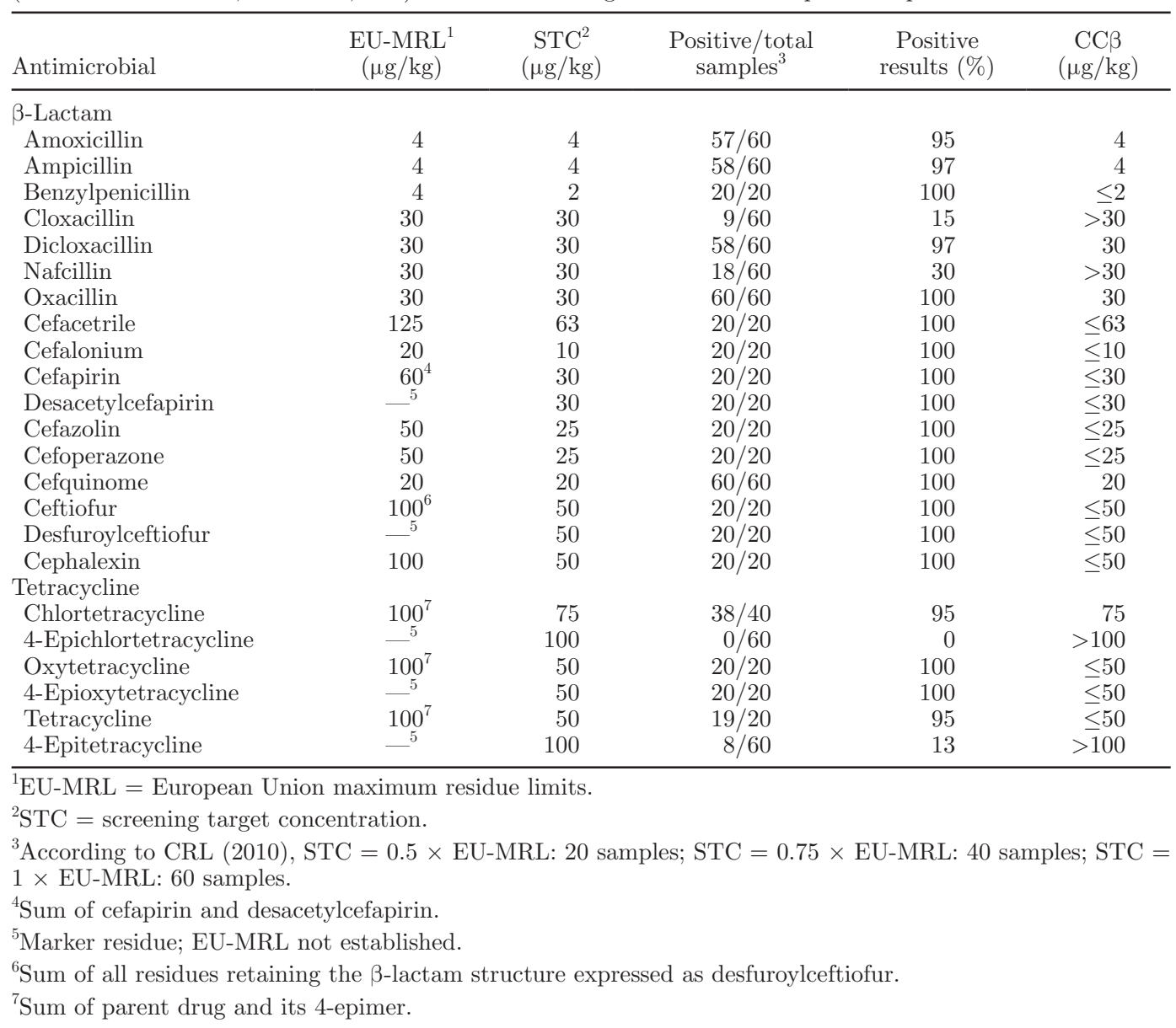

The CC $\beta$ for tetracyclines was also lower than EUMRL for chlortetracycline (ewe milk: $\leq 50 \mu \mathrm{g} / \mathrm{kg}$; goat milk: $75 \mu \mathrm{g} / \mathrm{kg})$, oxytetracycline $(\leq 50 \mu \mathrm{g} / \mathrm{kg})$, and tetracycline $(\leq 50 \mu \mathrm{g} / \mathrm{kg})$. Regarding the 4-epimers of these tetracyclines, only 4-epioxytetracycline was detected by the Charm MRL BLTET test below EUMRL (ewe milk: $75 \mu \mathrm{g} / \mathrm{kg}$; goat milk: $\leq 50 \mu \mathrm{g} / \mathrm{kg}$ ). For 4-epichlortetracycline and 4-epitetracycline, the CC $\beta$ were above EU-MRL $(\mathrm{CC} \beta>100 \mu \mathrm{g} / \mathrm{kg})$.

These results $(\mathrm{CC} \beta \leq \mathrm{EU}-\mathrm{MRL})$ are similar to those obtained by Reybroeck et al. (2011) using the Charm MRL-3 test to detect $\beta$-lactams in cow milk samples, the only exception being cloxacillin, which was also detected by those authors at a concentration below EU-MRL $(14 \mu \mathrm{g} / \mathrm{kg})$. Salter et al. (2011) also obtained appropriate sensitivity with the Charm 3 SL3 $\beta$-lactam test according to safe level/tolerance as stipulated by the FDA (2005).

\section{Effect of Acidiol on the Test Response}

The presence of acidiol in milk samples had no influence on the response of the Charm MRL BLTET test. All the antibiotic-free milk samples from ewes and goats spiked with acidiol were clearly negative (Figure 1) regardless of the system used for the interpretation of the results. No interference was observed with milk samples spiked with benzylpenicillin $(4 \mu \mathrm{g} / \mathrm{kg})$ or with oxytetracycline $(100 \mu \mathrm{g} / \mathrm{kg})$ regardless of whether interpretation of the results was made visually or instrumentally.

So far, no study exists on the influence of preservatives on the performance of the receptor-binding assays for the detection of antibiotics in milk. Only studies with microbial inhibitor tests have been carried out, as the presence of preservatives may interfere with the growth of the microorganism in the test, increasing the incidence of questionable or false-positive results (Molina et al., 2003b).

The results obtained in this study show the suitability of the Charm MRL BLTET test for the detection of antibiotic residues of $\beta$-lactams and tetracyclines in ewe and goat milk. The Charm MRL BLTET test was neither influenced by the distinct composition of ewe and goat milk, characterized by elevated fat and 

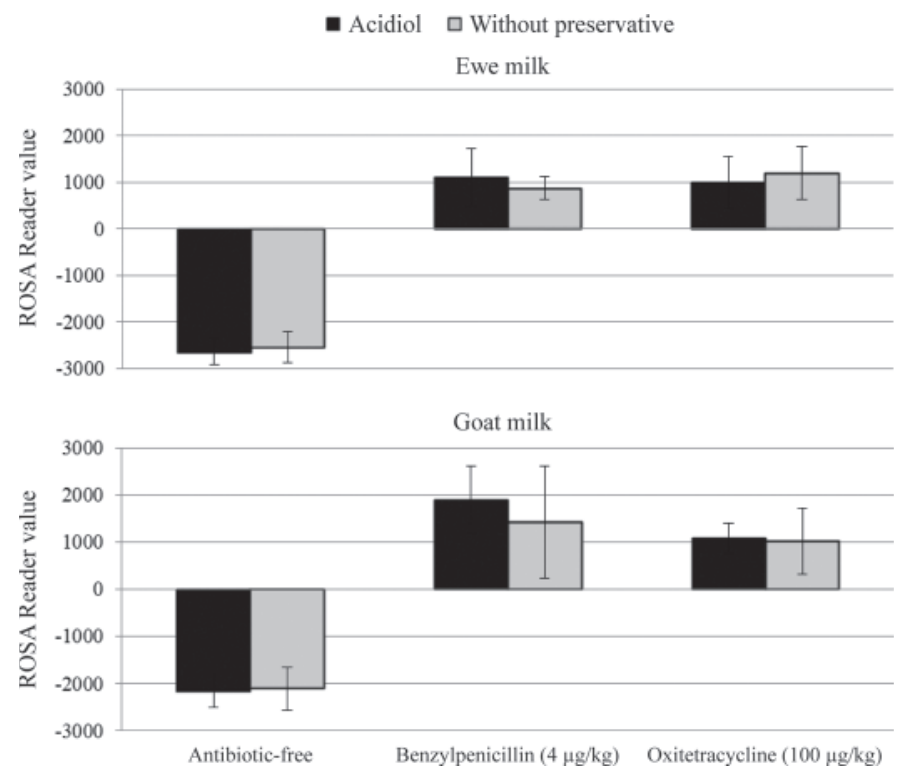

Figure 1. Effect of acidiol in ewe and goat milk samples on the results of the Charm maximum residue limits $\beta$-lactam and tetracycline test (Charm Sciences Inc., Lawrence, MA). ROSA = Rapid One-Stip Assay.

protein contents compared with cow milk, nor by the high SCC, which some authors related to false-positive results in the microbial screening tests (Althaus et al., 2003) and receptor-binding assays (Contreras et al., 1997).

These results are of great relevance for ovine and caprine milk quality control programs. The Charm MRL BLTET test enables the fast and efficient control of antibiotics in farms and the dairy industry, thus guaranteeing the absence, or presence below legally established EU-MRL, of most $\beta$-lactams and tetracyclines. Moreover, the Charm MRL BLTET test was not affected by the presence of the preservative acidiol in milk samples, which also allows its use in milk quality control laboratories which normally analyze ewe and goat milk with acidiol.

The only aspects of the test which could possibly be improved are the test duration (16 min), which is relatively long when compared with other protein receptor-binding tests usually applied in cow milk (1-9 min), and the need to dilute the ewe and goat milk samples with a specific buffer before analysis. In this sense, it is worth mentioning that the manufacturers are currently working on a new version of the Charm MRL BLTET test that does not require the buffer and has a shorter incubation time, taking advantage of the high specificity and adequacy of receptors used in the ROSA Charm technology.

\section{CONCLUSIONS}

The Charm MRL BLTET test displays a high specificity for the detection of antibiotics in ewe and goat milk with adapted test procedures, regardless of whether the interpretation of the results is carried out visually or instrumentally. The detection capability obtained for the Charm MRL BLTET test indicates a high sensitivity to most $\beta$-lactam antibiotics considered, except for cloxacillin and nafcillin. As for tetracyclines, the Charm MRL BLTET test was also able to detect chlortetracycline, oxytetracycline, tetracycline, and 4-epioxytetracycline at or below EU-MRL. Acidiol had no effect on the performance of the test. The performance characteristics of the Charm MRL BLTET test makes it suitable to be included in ewe and goat milk quality programs as a fast, routine method on farms and in the dairy industry.

\section{ACKNOWLEDGMENTS}

This work forms part of the Project AGL2009-11524 financed by the Ministerio de Ciencia e Innovación (Madrid, Spain). The authors are grateful to Fatro S.p.A. (Bologna, Italy) and ACS Dobfar S.p.A. (Milan, Italy) for kindly providing cefacetrile and desacetylcefapirin, respectively. Moreover, the authors thank Charm Sciences, Inc. (Lawrence, MA) and especially Wilbert Kokke from Charm Sciences Inc. and Raúl Gómez from Grupo Taper, S.A. (Madrid, Spain) for their support.

\section{REFERENCES}

Althaus, R., A. Torres, C. Peris, M. C. Beltrán, N. Fernández, and M. P. Molina. 2003. Accuracy of BRT and Delvotest microbial inhibition tests as affected by composition of ewe's milk. J. Food Prot. 66:473-478.

Berruga, M. I., M. C. Beltrán, B. Novés, A. Molina, and M. P. Molina. 2011. Effect of penicillins on the acidification of yogurt made from ewe's milk during the storage. Pages 145-149 in Science and Technology Against Microbial Pathogens. Research, Development and Evaluation. A. Mendez-Vilas, ed. World Scientific Publishing, Hackensack, NJ.

Berruga, M. I., M. Roca, M. P. Molina, and A. Molina. 2009. Evaluation of receptor-based tests for the detection of penicillins and tetracyclines residues in ewe milk. Poster no. 7.15 presented in Conf. 7 (Analysis \& Sampling) of IDF World Dairy Summit. Berlin, Germany. http://www.idf-germany.com/fileadmin/user_upload/ idf-germany/download/FinalProgrammeWDS2009EN_000.pdf.

Boletín Oficial del Estado. 2011. Real Decreto № 752/2011 de 27 de mayo, por el que se establece la normativa básica de control que deben cumplir los agentes del sector de leche cruda de oveja y cabra. BOE, 9 de Junio de 2011, 137:58609-58630.

Charm, S. E., and E. Zomer. 1995. The evolution and direction of rapid detection/identification of antimicrobial drug residues. Pages 224-233 in Proc. Residues of antimicrobial drugs and other inhibitors in milk. International Dairy Federation Special Issue 9505. Int. Dairy Fed., Brussels, Belgium.

Community Reference Laboratories Residues (CRL). 2010. Guidelines for the validation of screening methods for residues of veterinary 
medicines. Accessed Jan. 20, 2010. http://ec.europa.eu/food/ food/chemicalsafety/residues/lab_analysis_en.htm.

Contreras, A., M. J. Paape, A. L. Di Carlo, R. H. Miller, and P. Rainard. 1997. Evaluation of selected antibiotic residue screening tests for milk from individual goats. J. Dairy Sci. 80:1113-1118.

European Union. 2002. Commission Decision 2002/657/EC of $12 \mathrm{Au}-$ gust 2002 implementing Council Directive 96/23/EC concerning the performance of analytical methods and the interpretation of results. Off. J. L221:8-36.

European Union. 2009. Regulation (EC) № 470/2009 of 6 May 2009 laying down Community procedures for the establishment of residue limits of pharmacologically active substances in foodstuffs of animal origin, repealing Council Regulation (EEC) № 2377/90 and amending Directive 2001/82/EC of the European Parliament and of the Council and Regulation (EC) № 726/2004 of the European Parliament and of the Council. Off. J. L152:11-22.

European Union. 2010. Regulation (EU) № 37/2010 of 22 December 2009 on pharmacologically active substances and their classification regarding maximum residue limits in foodstuffs of animal origin. Off. J. L15:1-72.

FDA (Food and Drug Administration Center for Veterinary Medicine). 2005. MI-05-05: Tolerance and/or Safe Levels of animal drug residues in milk. Accessed Nov. 14, 2011. http://www.fda. gov/Food/FoodSafety/Product-SpecificInformation/MilkSafety/ CodedMemoranda/MemorandaofInformation/ucm077350.htm.

Haenlein, G. F. W. 2001. Past, present and future perspectives of small ruminant dairy research. J. Dairy Sci. 84:2097-2115.

International Dairy Federation (IDF). 2002. Guidelines for the standardized description of immuno- or receptor assays for the detection of antimicrobial residues. IDF Standard No. 188. Int. Dairy Fed., Brussels, Belgium.

International Dairy Federation (IDF). 2010. Current situation \& compilation of commercially available screening methods for the detection of inhibitors/antibiotic residues in milk. IDF Bulletin No. 442. Int. Dairy Fed., Brussels, Belgium.

Molina, A., M. P. Molina, R. L. Althaus, and L. Gallego. 2003a. Residue persistence in sheep milk following antibiotic therapy. Vet. J. $165: 84-89$.
Molina, M. P., R. L. Althaus, S. Balasch, A. Torres, C. Peris, and N. Fernández. 2003b. Evaluation of screening test for detection of antimicrobial residues in ewe milk. J. Dairy Sci. 86:1947-1952.

Packham, W., M. C. Broome, G. K. Y. Limsowtin, and H. Roginski. 2001. Limitations of standard antibiotic screening assays when applied to milk for cheesemaking. Aust. J. Dairy Technol. 56:15-18.

Pengov, A., and A. Kirbis. 2009. Risks of antibiotic residues in milk following intramammary and intramuscular treatments in dairy sheep. Anal. Chim. Acta 637:13-17.

Phillips, I., M. Casewell, T. Cox, B. De Groot, C. Friis, R. Jones, C. Nightingale, R. Preston, and J. Waddell. 2004. Does the use of antibiotics in food animals pose a risk to human health? A critical review of published data. J. Antimicrob. Chemother. 53:28-52.

Requena, R., S. Balasch, C. Peris, M. Rodríguez, and N. Fernández. 2010. Dose response of lactating dairy ewes during suckling and milking to bovine somatotropin. J. Anim. Sci. 88:3136-3144.

Reybroeck, W., S. Ooghe, H. F. De Brabander, and E. Daeseleire. 2010. Validation of the Beta-s.t.a.r 1+1 for rapid screening of residue of 3-lactam antibiotics in milk. Food Addit. Contam. 27:1084-1095.

Reybroeck, W., S. Ooghe, H. F. De Brabander, and E. Daeseleire. 2011. Validation of the Charm MRL-3 for fast screening of $\beta$-lactam antibiotics in raw milk. J. AOAC Int. 94:373-382.

Salama, A. A. K., X. Such, G. Caja, M. Rovai, R. Casals, E. Albanell, M. P. Marín, and A. Martí. 2003. Effects of once versus twice daily milking throughout lactation on milk yield and milk composition in dairy goats. J. Dairy Sci. 86:1673-1680.

Salter, R. S., D. Douglas, L. McRobbie, J. Quintana, D. Legg, J. Schwartz, D. Conaway, C. McPhee, S. Saul, and R. Markovsky. 2011. Validation of the Charm 3 SL3 $\beta$-Lactam test for the screening raw milk in compliance with the U.S. pasteurized milk ordinance. J. AOAC Int. 94:348-357.

Sanders, P., A. Bousquet-Melou, C. Chauvin, and P. L. Toutain. 2011 Utilisation des antibiotiques en élevage et enjeux de santé publique. INRA Prod. Anim. 24:199-204.

Zeng, S. S., S. Hart, E. N. Escobar, and K. Tesfai. 1998. Validation of antibiotic residue tests for dairy goats. J. Food Prot. 61:344-349. 